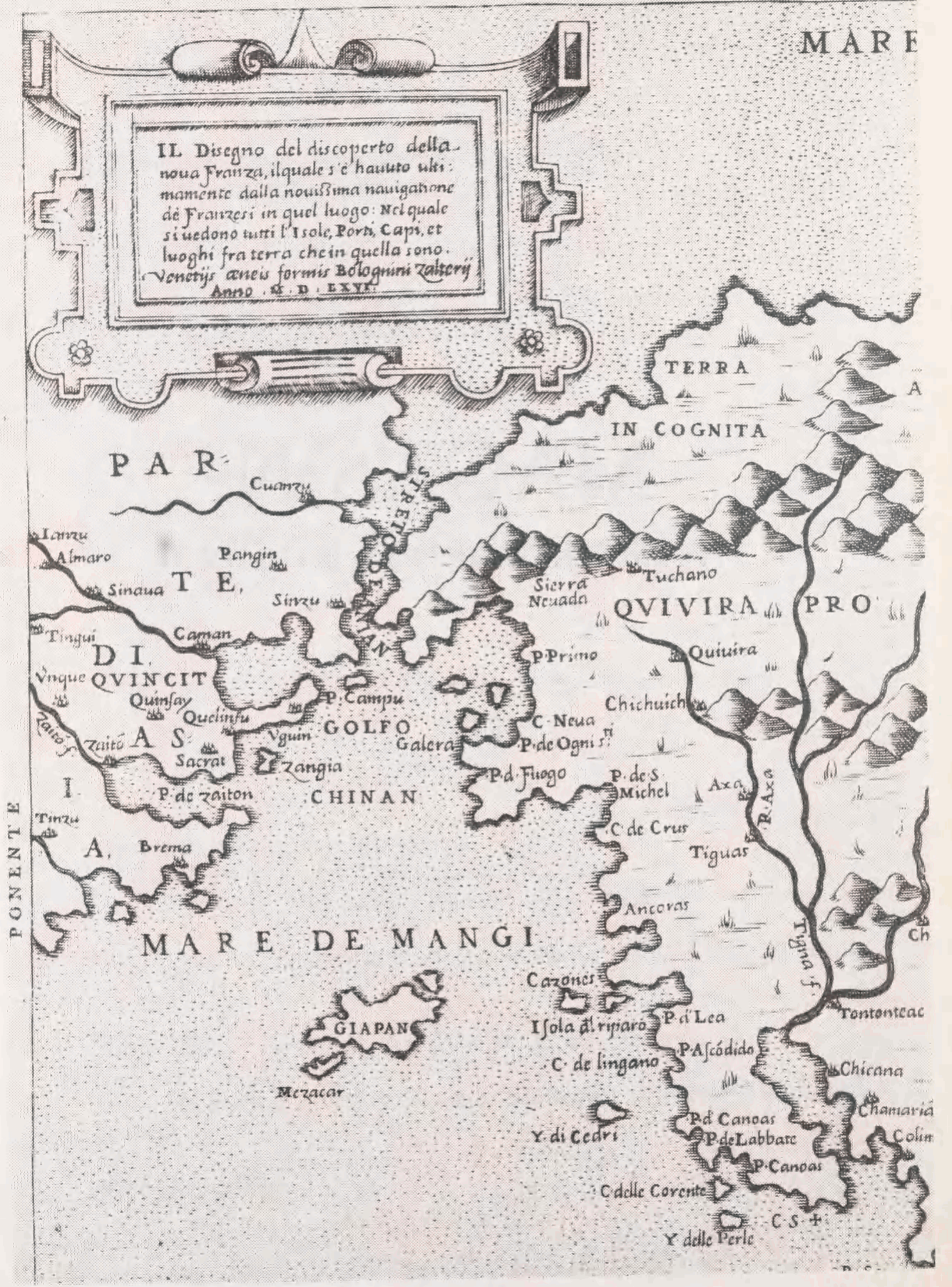

Fig. 1. Udsnit af Zalteris' kobberstukne kort over Nordamerika og Nordøstasien med "Streto de Anian" fra 1566 . Kortets mål: 28,0 x $40,5 \mathrm{~cm}$. 


\section{Hidtil ukendt Vitus Bering-kort i Det kongelige Biblioteks eje}

af førstebibliotekar Ib Rønne Kejlbo

Hidtil ukendt Vitus Bering-kort fra den 1. Kamtjatka-ekspedition, 1725-30, prosenteret $i$ anledning af 250 året for Vitus Berings død, i.e. 1991. - Med en kort gennemgang af Nordøstasiens kortlagning før Bering.

\section{Anian-Strædet}

På meget af kortmaterialet over Det stille Ocean fra 1500-tallet og et par århundreder frem ses tit et nordligt stræde mellem Amerika og Asien. Det er ofte benævnt Anian-Strædet. Det ældste kendte kort, hvorpå Anian-strædet manifesterer sig med navns nævnelse, er Zalterios' kort over Nordamerika fra 1566. Herpå ses "Stretto di Anian" afsat mellem Nordamerika og Nordøstasien. Sydligere og i forlængelse af strædet ses Chinan bugten og Mangi havet. Marco Polo omtaler i sin rejseskildring Anian som en provins i det sydlige Kina (fig. 1). Chinan - benævnelsen for Sydkina - ses ofte på tidligt, kartografisk materiale og er tit afsat de mærkværdigste steder.

Anian-Strædet, således som det blandt andet fremtræder på Zalterios' kort, må betegnes som skrivebordskartografi; det har intet reelt med kortlægning at gøre. Det sker først, da Desnev i 1648 sejler fra Lena mod øst og runder Østkap.

\section{Nordøstpassagen og Nordvestpassagen}

I begyndelsen af 1700-tallet var russiske nybyggere og opdagelsesrejsende over land nået frem til Det okotske Hav. Peter den Store intensiverede ud- 
forskningen af Sibirien, bl.a. ved at udsende den 1. Kamtjatka-ekspedition i 1725. Én af dennes opgaver var at undersøge, om der eksisterede en nordlig sejlrute mellem Det atlantiske Ocean og Det stille Ocean. Teorien om at en sådan fandtes, debatteredes tidligt i litteraturen; f.eks. i Das Buch von der Botschaft Wassilis, des Moskauer Grossfürsten, an Papst Klemens VII in welchem wahrheitsgetreu die Lage des Landes das den Alten unbekannt war, die Religion, die Sitten des Volkes sowie die Ursachen der Botschaft werden, skrevet af Paulus Iovius efter storfyrst Dimitri Gerrassimows diktat. Heri gives udtryk for sandsynligheden for eksistensen af en nordøst-passage: "das man höchst-wahrscheinlich am rechten Ufer entlang zu Schiff nach Catay gelangen kann". Værket udkom 1525, først på latin og senere på mange andre sprog.

I 1629 udgav sakseren George Schleissing: Neu entdecktes Sieweria (Sibirien). I denne læses: "Die Strasse von Waigatsch ist nach den Aussagen der Samojeden zu einer bestimmten Zeit schiffbar. Zumindest wäre es nach meiner Meinung und der Meinung glaubwürdiger Leute möglich, wenn man die Mittel dazu aufbieten würde, ein Seeweg nach Ostindien zu finden."

Russerne besejlede i begyndelsen af 1500 -tallet en del af denne søvej, nemlig området fra Det hvide Hav til Obs munding.

At finde en sejlbar nordlig passage var mange europæiske lande interesserede i. I 1556 foretog englænderen Stephen Borrough en rejse til Kolas udmunding og derfra videre til Novaja Semlja og Vajgat.

I august 1568 udarbejdede Stephan Borrough og hans bror William planer for en ny nordøstpassage-ekspedition. De blev imidlertid ikke realiseret. Det eneste kartografiske resultat af Stephan Borroughs ekspedition 1556 menes at være, at hans oplysninger om Novaja Semlja sandsynligvis danner grundlag for Ortelius' gengivelser af Norvaja Semlja i Teatrum orbis Terrarum, Amsterdam 1570.

I 1594 stod hollænderen Willem Barents (1550-97) i spidsen for en ekspedition, som omfattede fire skibe. Den skulle søge efter den nordøstlige s $\varnothing$ vej til Kina; under denne søgning opdagede man Bjømøya og Spitsbergen.

I 1596 tog Barents atter af sted, denne gang kun med to skibe. Han nåede Nord-Kap, fortsatte mod nord via Bjørnøya og Spitsbergen til $80^{\circ}$ n.br. I Karahavet blev han stoppet af isen og måtte overvintre. Midt i juni $1597 \mathrm{sad}$ skibene stadig fast. Barents mente, at den eneste mulighed for redning var at forsøge at nå frem til Kolahalvøen, dels ved hjælp af en båd, dels til fods over isen. Det var en strækning på $250 \mathrm{~km}$. Barents nåede ikke hjem, men det gjorde flere af mændene. I 1871 fandt norske sælfangere ekspeditionens overvintringshytte; her fandt de bl.a. Barents dagbog. Barents togt var det sidste hollandske opdagelsestogt til de polare egne. Senere blev det polar- 


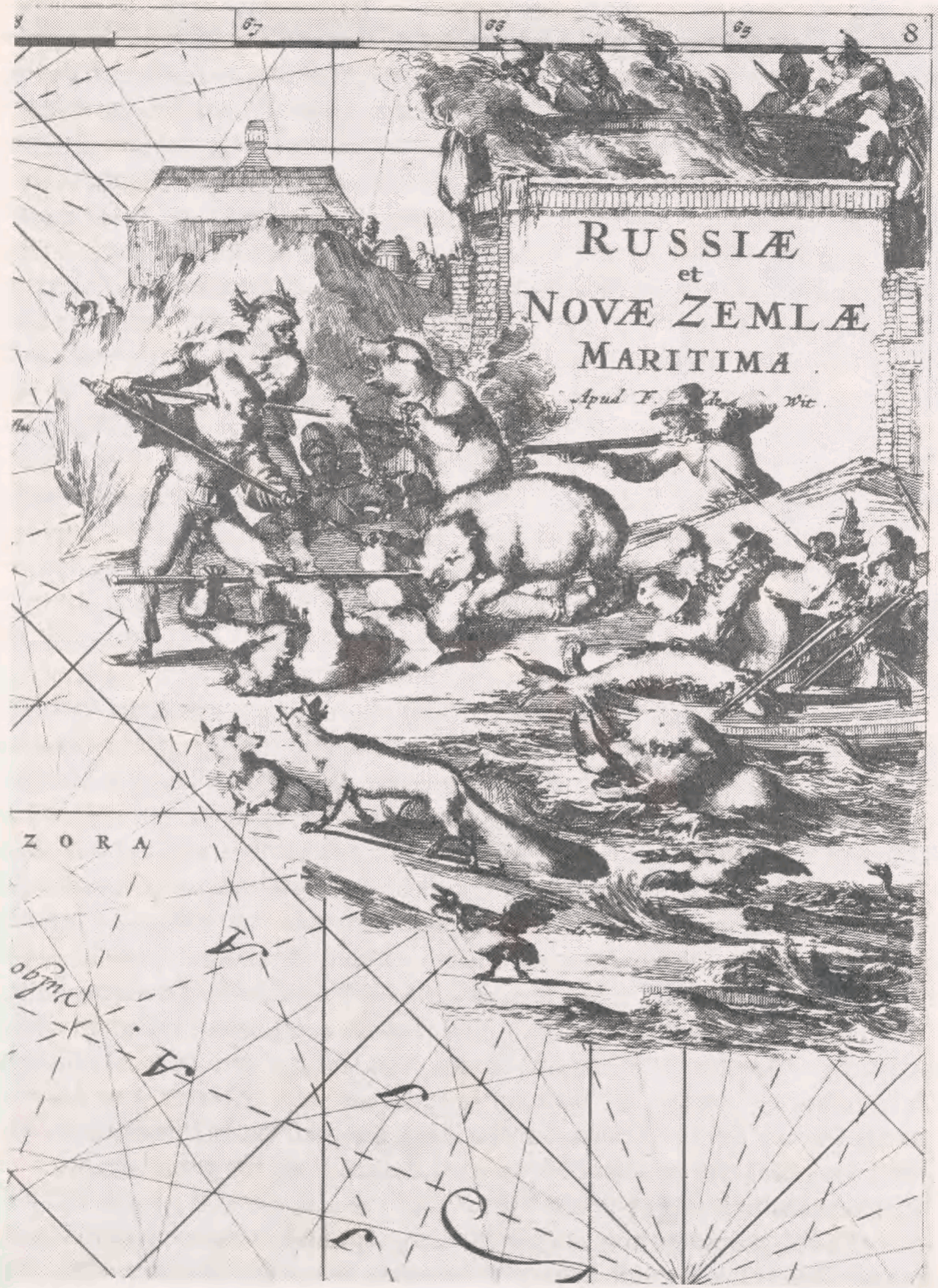

Fig. 2. Vignet fra F. de Wits kobberstukne kort over Rusland og Nova Zelma ca. 1675. Kortets mål: $52,0 \times 58,0 \mathrm{~cm}$.

havets dyreliv, der appellerede til sejlads i de arktiske have. (fig. 2). Englænderne derimod fortsatte med søgningen efter Nordøstpassagen og dermed 
vejen til Kina og rigdom. Englænderen Henry Hudson (ca. 1550-1611) gjorde forsøg på gennemsejling af Nordøstpassagen, men måtte også opgive, og bortset fra, at man fik bekræftelse på Barents oplysninger om det rige dyreliv i de nordlige have, gav ekspeditionen intet resultat. I 1610 forsøgte Hudson at gå gennem Nordvestpassagen, men også dette mislykkedes. Englænderen William Baffin (1584-1622) fors $\emptyset$ gte sig ligeledes, men havde heller ingen større succes. Også i Danmark nærede man ønske om at finde en nordlig søvej til Kina. Christian IV satsede således på Nordvestpassagen og sendte Jens Munk (1579-1628) af sted i 1619 for at finde en nordlig søvej fra Det atlantiske Ocean mod vest til Det stille Ocean. Ekspeditionen bestod af 2 skibe og 63 mand. Jens Munk overvintrede i Hudson Bay. I januar 1620 var de fleste af ekspeditionens deltagere syge af skørbug, og i juni var der foruden Jens Munk selv kun 2 overlevende tilbage. Disse fik gjort ét af skibene sejlklart og nåede hjem. Jens Munk skrev en lille beretnig om ekspeditionen. Den blev udgivet i 1624 med titlen Navigatio Septentrionalis, 1624.

\section{Semen Desnev runder Nordøstkap i 1648}

Det er forholdsvis sparsomme oplysninger, man har om kosakken Desnev, men formodentlig stammer han fra "Gross-Ustjug"; han har gjort tjeneste i Tobolsk og Jenisejsk, og det vides, at han opholdt sig som kosak i Jakutskområdet, hvor koloniseringen påbegyndtes i 1632 . I 1640 fik han ordre til at inddrive tributter langs floden Pjana. På tilbagevejen herfra til Jakutsk blev Desnev overfaldet af tungusere og blev såret $\mathrm{i}$ foden, men slap levende fra overfaldet. Fra to år senere findes der informationer om, at Desnev befandt sig i Ojmjakon ved Indigirkas $\emptyset v r e ~ 1 \varnothing b$. Her blev hans afdeling på 12 mand overfaldet af krigeriske tungusere, men fik hjælp fra fredelige tungusere og jakutere. Derefter fortsatte Desnev med sine 12 kosakker ad Indigirka til Ishavet og til lands videre $\emptyset$ stpå til floden Alaseja og videre frem til området Jukagirien, et område der ikke tidligere havde ydet tributter. Fra Alaseja nåede Desnev frem til floden Kolyma, hvor han traf Michail Staduchin - berømt for opdagelse af "den ukendte flod Kolyma" og for grundlæggelsen af stationen Nishe-Kolymsk ved Kolyma.

I 1647 udrustede købmanden Cholmogorer Fedot Alexejewitsch Popow et togt, der bl.a. havde til opgave at indsamle hvalros-stødtænder; disse var meget eftertragtede. Desnev blev tilbudt at komme med, han skulle bl.a. udvide tributområdet. 1647 sejlede fire skibe fra Kolymas munding. Togtet blev imidlertid ingen succes p.g.a. isvanskeligheder.

Trods det dårlige resultat i 1647 arrangerede Desnev et nyt togt i 1648, 
denne gang med 6 skibe og 90 mand. I 1654 beskriver Desnev i et brev til zar Alexsi Michailowitch, at han på sit togt 1648 sejlede fra floden Kolymas munding i ishavet til floden Anadyr på den anden side af Tjukterhalvøen, hvilket betyder, at Desnev i så fald havde sejlet rundt om Nordøstkysten.

Afrejsen fandt sted den 20. september 1648. Desnev mistede forbindelsen med den $\emptyset$ vrige del af ekspeditionen. Hans skib drev forbi Anadyr og blev kastet ind på kysten. Efter forliset vandrede de overlevende rundt i ti uger, sultne, frysende, barfodede og uden kendskab til landskabet. Af det oprindelige mandskab var nu kun 12 tilbage.

\section{Kamtjatka}

De første oplysninger om Kamtjatka nåede russerne i midten af 1600-tallet, gennem bl.a. Desnev og kojakkerne. Men den egentlige opdagelse og beskrivelse skyldes Wladimir Atlassov, der nåede frem til halvøen på en ekspedition i årene 1697-1699. Ekspeditionen byggede i ikke ringe grad på Desnevs erfaringer. I 1696 havde den jakutiske kosak Luka Morosko fået ordre til at undersøge området ved floden Obuka, der flyder ud i det, som i dag kaldes Beringhavet, omkring $62^{\circ}$ n.br. Han nåede imidlertid ikke frem til de $\emptyset$ skede mål. Det gjorde Atlassov derimod. Han drog i 1697 ud med 60 af sine egne mænd og 60 tributpligtige beboere fra Anadyrsk. Han vendte hjem 1699 med mange gode geografiske oplysninger om Kamtjatka. I 1716 foretog russerne på initiativ af Peter den Store deres første sejlads tværs over Det okotske Hav. Det anvendte fartøj var blevet bygget i Okotsk. Alt, hvad man i Moskva og Tobolsk vidste om Østsibirien, er nedfældet i Semen Remesos: Skizzenbuch von Sibirien 1697-1700. I dette værk findes et kort med titlen "Skizze aller Sibirischen Städte und Länder 1698". Kamtjatka er gengivet som en $\emptyset$; det samme gælder Korea.

\section{Svenske krigsfanger kortlægger Sibirien}

I 1730 udkom Das Nord- und Östliche Teil von Europa und Asia med et tilhørende kort, udgivet første gang i Nürnberg, senere i oversættelse flere steder. Ophavsmanden til værket var den tidligere svenske krigsfange Philip von Stralenberg. Han havde oparbejdet en stor viden om Sibirien, blandt andet gennem samtaler med karolinske krigsfanger, der i stort tal blev sendt til forskellige regioner i Sibirien. De fungerede som meddelere til Stralenberg. Trafikken til Kamtjatka, som var blevet opdaget 1697, gik over land. At krydse 


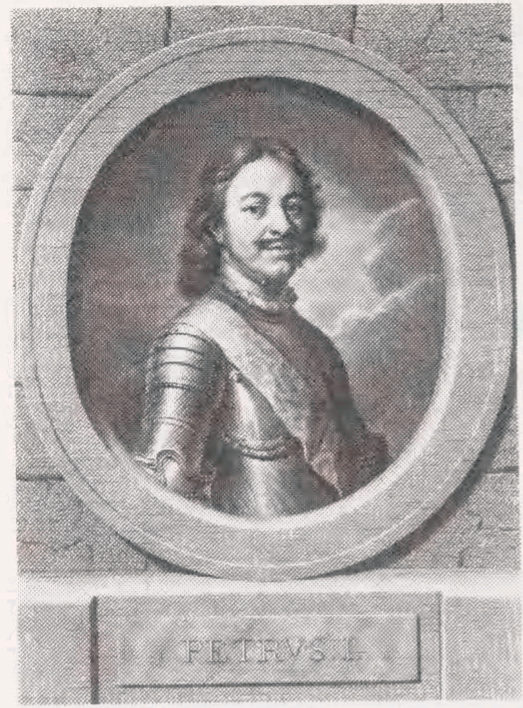

Fig. 3. Zar Peter den Store af Rusland (1672-1725). Kobberstik af Johann Friedrich Bause (1738-1814). Stukket i Leipzig 1766 efter forlæg af Le Roy, Paris 1717.
Det okotske Hav forekom mange umuligt dog ikke Peter den Store. Han beordrede et antal søkyndige, svenske krigsfanger til det okotske område, hvor de skulle undersøge mulighederne for sejlads tværs over Det okotske Hav til Kamtjatka. Undersøgelseme førte til, at det fra 1717 blev almindeligt at sejle fra Okotsk-området tværs over det Det okotske Hav til Kamtjatka.

I 1720 fik Stralenberg i Tobolsk besøg af Gottlieb Messerschmidt, som skulle ud på en længere rejse i Sibirien. Messerschmidt fik tilladelse til at tage Stralenberg med; også nogle andre krigsfanger fik lov at deltage. De nåede frem til Tomsk, hvor der fandtes mange svenske krigsfanger. Af dem fik Stralenberg vigtige oplysninger, som han kunne indtegne på sit kort. Efterhånden nåede Messerschmidt og følge frem til Krasno-

jarsk. Her erfarede de, at der var sluttet fred mellem Rusland og Sverige. Stralenberg kunne nu rejse hjem til Sverige som en fri mand. Han tiltrådte tilbagerejsen. Vejen var lang og befolkningen ikke altid lige fredelig. I 1723 nåede han til Moskva.

Efter hjemkomsten til Sverige arbejdede han videre med sine kort. Stralenbergs kort bygger hovedsagelig på mundtlige kilder og har mange fejl blandt de mange gode oplysninger. Men hans kort er absolut et meget vigtigt led i den russiske kartografihistorie.

Stralenbergs kort var udsat for megen dramatik. Under en ildebrand i Tobolsk i 1715 forsvandt kufferten med hans kort, efter at han havde kastet den ud af vinduet. På opfordring udarbejdede han to nye sæt. I 1717 forbød guvern $\varnothing \mathrm{r}$ Gagarin Stralenberg at udøve kartografisk virksomhed. Endvidere beslaglagde han det ene sæt kort - heldigvis uden viden om, at Stralenberg havde sendt det andet sæt til statssekretæren Josias Cederhielm i Moskva.

\section{Atlassov sender kort til Moskva i 1699}

Peter den Store (fig. 3) må have haft kendskab til Desnevs opdagelser. Derpå tyder et kort, som W. Atlassov sendte til Moskva i 1699, på hvilket Asien ses adskilt fra Amerika. Dette kort med nogle ændringer sendte Peter den Store i 1721 til Videnskabernes Akademi i Paris. Geografen Johann Baptist Homann 
publicerede det. I 1719 blev det besluttet at sende en hemmelig ekspedition til Nordøstasien. Ekpeditionsledere var Peter Luzhin og Ivan Yevereinnov. De skulle efter ordre fra Peter den Store udforske Kurillerne og om muligt Japan. De skulle også tegne et godt kort over de besøgte lokaliteter. Ekspeditionen forløb desværre ikke godt.

Fig. 4. Udsnit af J.B. Homanns kobberstukne kort over Sibirien. Kortet illustrerer den totale mangel på kendskab i begyndelsen af 1700 -tallet til de reelle, geografiske forhold. Kortets mål: 51,5 x $57,5 \mathrm{~cm}$.

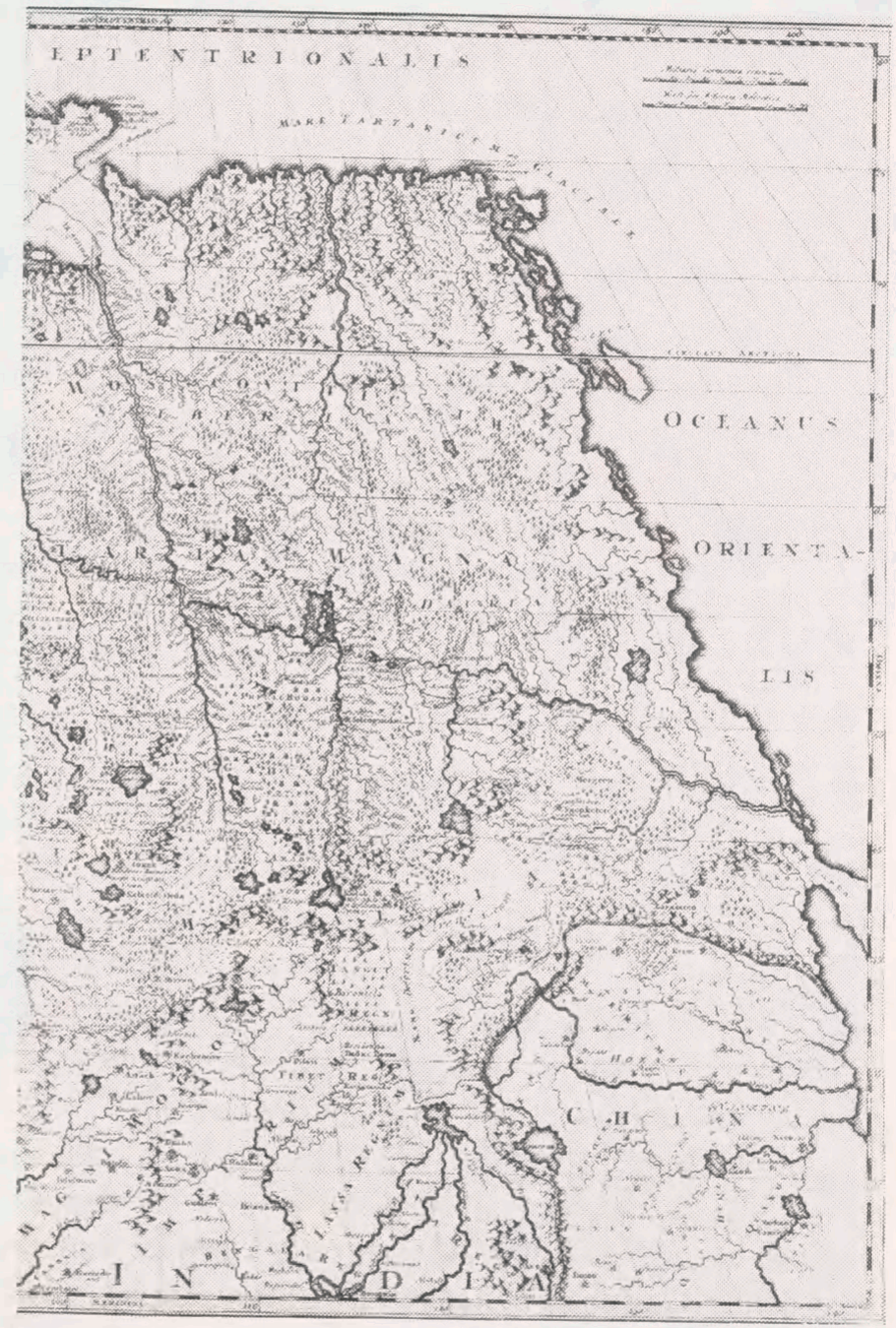

\section{Kamtjatka-ekspedition}

Blandt Europas videnskabsmænd herskede der i 1700-tallet stor interesse for viden om Ruslands udstrækning (fig. 4), for spørgsmålet vedrørende Amerikas og Asiens beliggenhed i forhold til hinanden samt for Nordvest- og Nordøst-passagerne. Én af de mest interesserede var den tyske videnskabs- 
mand Gottfried Leibniz, 1646-1716. Han var ivrig efter, at Peter den Store skulle iværksætte ekspeditioner, som kunne skaffe viden om det russiske rige.

Efter Store Nordiske Krigs afslutning 1721 fik Peter den Store den fornødne tid til at iværksætte en kæmpemæssig ekspedition. Han gav Apraksin ordre til at udruste en ekspedition og sørge for, at de bedst mulige mænd blev udtaget. Apraksin foreslog to kandidater til posten som leder af ekspeditionen: den ene van Verden, den anden Vitus Bering. Peter den Store valgte Bering.

Peter den Stores instruks til Bering:

"På Kamtjatka eller et andet sted skal der bygges eet eller to skibe med dæk.

Sejl med disse skibe langs landet mod nord, som da man ikke kender dets ende, må antages at være en del af Amerika.

Unders $\emptyset \mathrm{g}$ derfor, hvor landet løber sammen med Amerika, sejl til en eller anden europæisk koloni (for at spørge), eller hvis man møder et europæisk skib, skaf underretning om, hvad kysten hedder og skriv det op, gå selv i land og få pålidelige oplysninger, indfør dem på kortet og rejs hjem."

\section{Vitus Bering}

Vitus Bering (fig. 5) blev født i Horsens i 1681. Hans far, Jonas Svendsen, var toldvisiterer og kirkeværge. Moderen stammede fra den berømte Beringslægt, som bl.a. omfattede mange præster. Som ung tog Vitus Bering til søs. Han var flere gange i Ostindien. P̊̊ vej hjem fra én af disse rejser traf han nordmanden Cornelius Cruys, der på det tidspunkt var viceadmiral i den russiske marine. Bering blev af Cruys hvervet som underløjtnant i russisk tjeneste. Han giftede sig senere med den russiske admirals søster.

Den 5. februar 1725, 8 dage efter Peter den Stores død, modtog Vitus Bering fra zarinaen den afdøde zars instruks vedrørende den 1. Kamtjakaekspedition, og den 15 . maj 1725 begav ekspeditionen sig på vej fra Tobolsk mod Samarovsk ved Irtysj-floden. Derfra op ad Obi til Narim og videre largt op ad Ketfloden for derefter at drage over land til Jenisej. Fra Jenisej tog man med både ad Tungus til Illimas munding. Herfra fortsatte 39 mand under ledelse af danskeren Morten Spangberg til Ust-Kut. Her byggede man i løbet af vinteren femten pramme med henblik på næste års rejse. Bering tilbragte det meste af vinteren i Ilimsk. Han besøgte Irkutsk, hvor han indhøstede en 


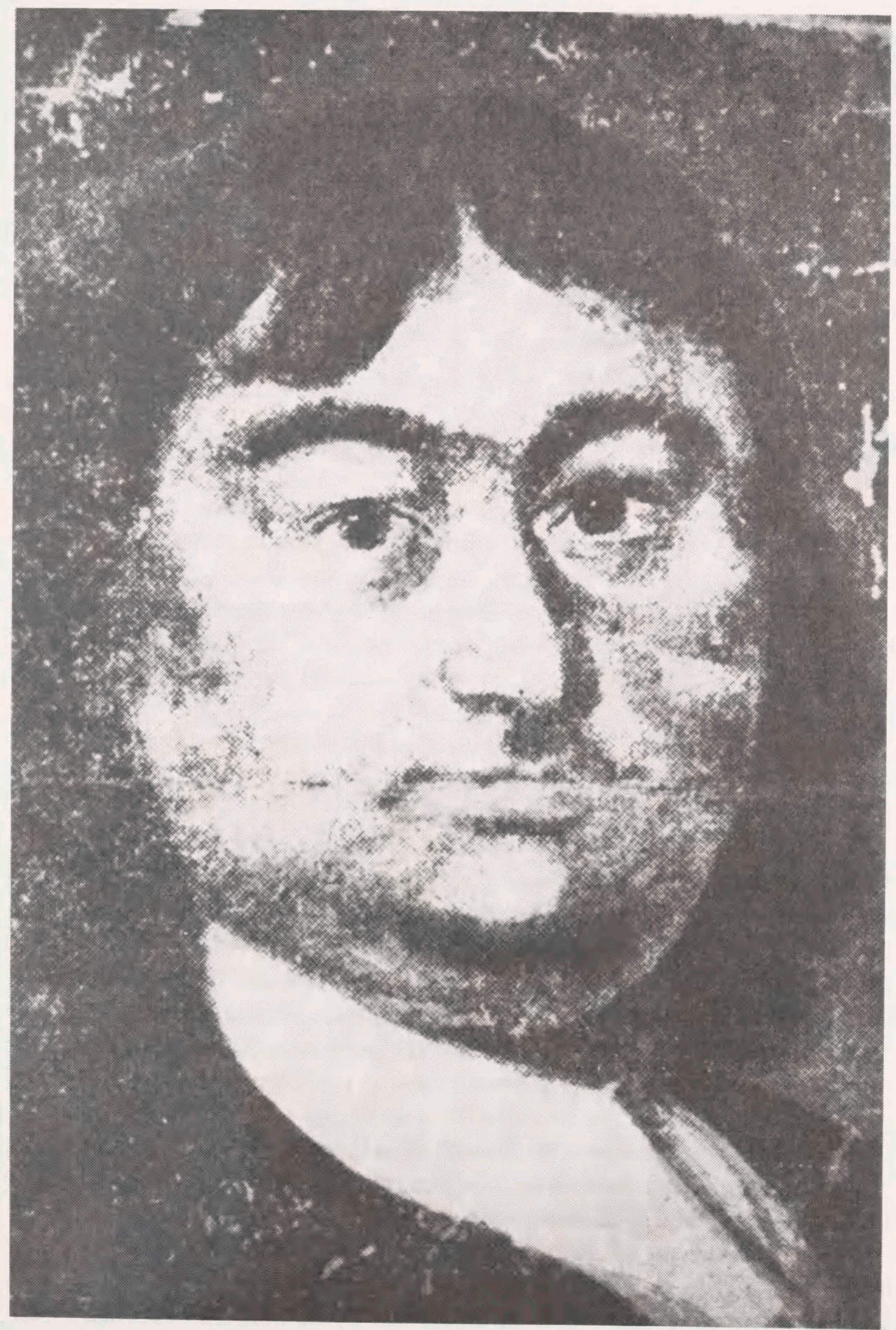

Fig. 5. Vitus Bering (1681-1741). Fotografi af maleri i russisk privateje. Efter tradition udlagt som værende Vitus Bering. 
del officiel viden om Østasien. I foråret 1726 samledes ekspeditionens deltagere i Ust-Kut, hvorfra de i pramme sejlede ned ad Lena til Jakutsk. Ekspeditionen delte sig atter. Bering tog med forholdsvis få folk af sted til hest til Okotsk, medens Spangberg skulle sejle ad Lena, Aldan og Maja til Yudoma nær Okotsk. Vinteren indhentede ham imidlertid, og ekspeditionen måtte overvintre, inden den nåede frem til Okotsk, hvor man byggede det skib, som skulle føre dem fra Okotsk til Kamtjatka. De nåede halvøens vestkyst og fortsatte tværs over til østsiden, hvor der blev bygget endnu et skib, som var færdigt i juli 1728.

Man indskibede proviant til et års forbrug til fyrretyve personer. Den 15. juli sejlede skibet Gabriel ud fra Kamtjatka-flodens munding mod nord. Under sejladsen nordpå observeredes den 11. august en $\emptyset$ i sydøstlig retning. Bering kaldte den San Lawrence. Det noteredes, at der var 5 hytter p̊̊ øen, men at den tilsyneladende var ubeboet. Den 15. august 1728 konstateredes det, at Asiens kyst ikke strakte sig længere nordp̊̊, men hovedsagelig vestpå. Gabriel befandt sig da på $67^{\circ}, 18^{\prime}$ n.br. Man satte derefter kursen sydpå uden at vide, hvor tæt man havde været p̊̊ Amerikas kyst.

I juni måned 1729 gjorde Bering et nyt forsøg på at nå Amerikas kyst. Han nåede ca. $200 \mathrm{~km}$. Øst på fra Okotsk, men vendte så om og sejlede tilbage. Tilbagerejsen fulgte iøvrigt stort set samme rute som udrejsen. Den 1. marts nåede de St. Petersburg.

\section{J.B. du Haldes kort}

Efter hjemkomsten tegnede Bering et kort, som viste ekspeditionens rejseruter. At Bering tegnede et sådant kort omtales af flere. En af kilderne er den franske jesuit, Jean Baptiste du Halde, der i sit værk Atlas Général de la Chine 1735 bringer et kobberstukket kort: "Carte des Pays/traversés par le Cap.ne Beerings/depuis la ville de Tobolsk jusqu' à Kamtscatka //. (fig. 6)

Teksten i du Haldes 4-bindsværk stammer hovedsagelig fra indsamlet materiale foretaget af jesuiterpræster i Kina på opfordring af Kejser Kang Hsi i årene 1708 til 1716.

Medens man således ved, hvorledes teksten i værket er fremkommet, ved man ikke, hvem der har udarbejdet forlægget til Beringkortet i Atlas Général de la Chine, 1735.

Der er ikke meget, der tyder på, at forlægget skal findes mellem de håndtegnede kopier af Berings kort, som kendes $\mathrm{i}$ dag. Ingen af dem har en konfiguration, som nøje svarer til du Haldes trykte kort fra 1735. Du Halde påstår selv, at hans forlæg er en kopi af et kort, som han har fået af den pol- 


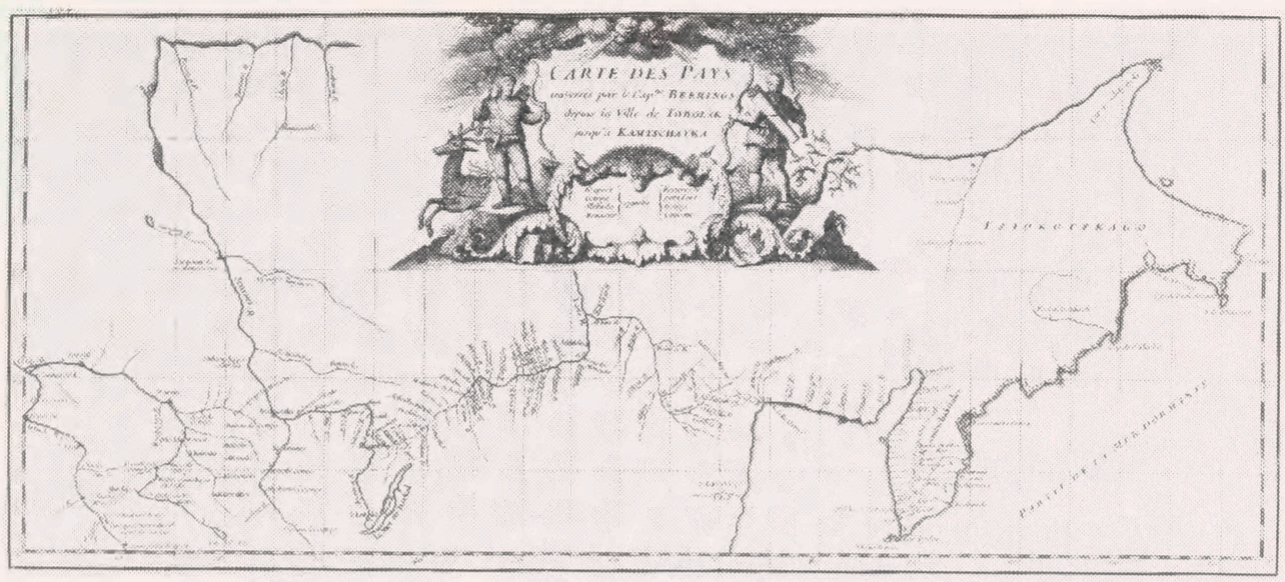

Fig. 6. J.B. du Haldes kort over Berings rejserute på den 1. Kamtjatka-ekspedition 1725-30. Kobberstik i Atlas Général de la Chine. Kortets mål: 23,4 x 53,0 cm.

ske konge. Mange tvivler på denne oplysnings rigtighed. Den almindelige opfattelse i Rusland er, at det var den franske astronom og geograf Joseph Nicolas Delisle, der bragte materiale og oplysninger til Frankrig. Han var i begyndelsen af 1726 kommet til St. Petersborg og havde dér i 1735 fået geografiske opgaver tildelt af Videnskabernes Akademi. Motivet til at opgive den polske konge som hjemmelsmand var at undgå, at Frankrig skulle få ubehageligheder med Rusland p.g.a. offentliggørelse af hemmeligholdte ekspeditionsoplysninger. Det vides, at Delisle den 25. juni 1730 sendte et brev til den franske minister Maurepas. I dette brev rapporterer han, at han inden længe vil sende en beretning om Berings rejse til ham. Delisle, der var geograf og ansat af Videnskabernes Akademi i Rusland, havde lejlighed til at se alt kartografisk materiale med relation til Rusland. Han havde lov til at sende astronomiske beregninger ud af landet, men ikke kartografisk materiale. Han var umådelig ihærdig, og det var ikke småting, han fik fra hånden. Han sendte således ca. 4.000 kopier til Frankrig, hvoraf langt det meste var lovligt. Efterhånden blev der fattet mistanke til ham om, at han sendte forbudt materiale til Frankrig, og han blev overvåget. Men fældende bevis fandt man ikke.

Man har hidtil haft kendskab til eksistensen af 12 håndtegnede, 1700tals kopier af dette kort, som Bering tegnede efter sin hjemkomst fra den 1. Kamtjatka-ekspedition. Blandt disse 12 kopier er én kopi i kegleprojektion, udarbejdet af danskeren A.R. Witken; denne kopi fra 1740 indgår i Fr. V's Atlas (bd. 44, pl. 88,) Det kongelige Bibliotek. (fig. 7)

L. Bagrow har udarbejdet en fortegnelse over de 12 nævnte, håndtegnede kopier af Berings kort. Den er offentliggjort i Geografisk Tidsskrift, bind 49, 1948-49, København, og lyder således: 
1. Topographical map from Tobolsk to the Okhotski fort (drawn in 1725 and 1726 during captain Bering's journey in Siberia) with notes indicating where aberrations of the compass were observed in towns and in other places. On the same map are indicated the settlements of the Ost-yaks, the Tunguzes, and other peoples. This map is in the Headarchives in Moscow.

2. Map drawn in 1732 by captain-commander Bering with indications of places through which he passed from Tobolsk to Kamchatkja. Drawn during the Siberian expedition.

3. Bering's map drawn by P. Chaplin and then redrawn by the geodesist Ivan Khanykov. This map is in the Cartographical Archives of the Academy of Science in Leningrad.

4. $\quad$ "Siya karta sochinisya $v$ sibirskoj expedici pri kamande ot flota kapitana Beringa ot Tobolska do Chyukockago ugla" [= This map was drawn in the Siberian expedition under command of seacaptain Bering from Tobolsk to the Chukotski corner). Is in the Kgl. Bibliotek in Stockholm, $1350 \times 580$ ).

5. "Sÿa Charta Sotzÿnÿsia Wsÿbÿrskoÿ Expedÿtzÿ Prÿ Camandie åt Flotta Capÿtana Berÿnga åt Tobolska då Tziokotzkago". 1932 x 545. In the Kgl. Bibliotek in Stockholm. C. Björkbom also refers to this map in his abovementioned article.

6. Sÿa Charta Sotzÿnÿsia Wsÿbÿrskoÿ Expedÿtzÿ Prÿ Comandie åt Flotta Capÿtana Berÿnga åt Tolbolka då Tziokotzkago" - Denna Charta är förfärdigad under Seberjska Expedition af den wid flottan comanderande Capitainen Bering, ifrån Tobolski till Tziokotzkago." 1313 x 510. The map is in the Krigsarkivet in Stockholm (33.36.b). It is identical with the preceeding map in the $\mathrm{Kgl}$. Bibliotek in Stockholm.

7. "Geografisk charta ifrån Tobolskoj til Tzjokotzkago förfärdigad Under Den Siberiske Expedition af den Wid Flottan Commenderande Capitainen". 130 $x$ 512. In the private collection of baron Klinkowström at Stavsund near Stockholm.

8. "Cette carte est faite sur le voyage que le Sieur Bering, capitaine de la flotte Russienne af fait de la ville de Tobolskoy en Sybérie jusqu'à Tziokoskago avec les gens qui étoint commandés avec luy, l'an 1725." 1330 x 570. In the Bibliotheque Nationale, Paris. This copy was received in the 1733 in Stockholm by the French envoy, count de Casteja, together with a translation from Swedish of Bering's report. This translation is also in the Bibliothèque Nationale now.

9. $\quad$ "Cette Carte est faite sur le voyage que le Siuer Bergings, capitaine de la flotte Russienne a fait de la ville Tobolski en Siberia jusqu'à Tziokotskago 


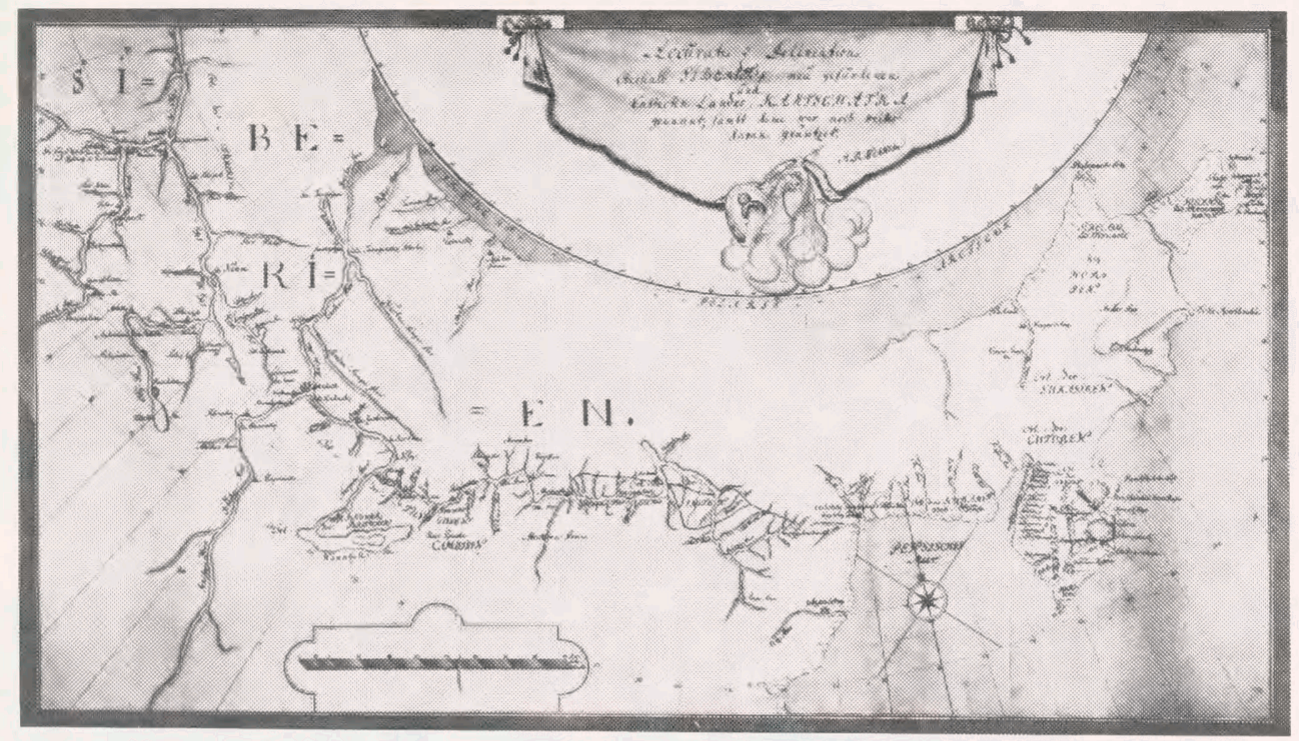

Fig. 7. Danskerem A.R. Witkens kort i kegleprojektion over den 1. Kamtjatka-ekspeditions rejserute. Håndtegning fra $1740 \mathrm{i}$ Frederik den Femtes Atlas bd. 44, pl. 88. Kortets mål: 43,5 x $74,0 \mathrm{~cm}$.

avec les gens qu'il commandoit l'an 1725 dessigné à Stockholm par le chevalier de Saumery l'an 1733". 1319 x 533. The map is in the Krigsarkivet in Stockholm (33.36.a). It seems to be a copy of the preceding map in the Bibliothèque Nationale in Paris. It was mentioned for the first time by captain $\mathrm{H}$. Köhlin who gives a reproduction of its eastern half.

10. "Accurate Delineation des Oberhalb Siberiens ney gefundenen und Entdeckten Landes, Kamtschatka genannt, sambt deme was noch weiter daran gräntzet. A.R. Witken." 740 x 435 . In the Kgl. Bibliotek, Copenhagen. The only one of all the copies drawn on conical projection.

11. "Carte de la Partie Occidentale de la Route du Capitaine Beerings de Tobolsk à la partie orientale de la Russie nouvellement découverte. Le cours de Rivière d'Angara jusqu'au Lac Baikal et le Lac Baikal, la Ville d'Irkoutsk et tout ca canton est marqué tiré de la Carte du Géodésiste Chatilovca. Aux sources de l'Irtis de 'Oby et du Iéniscèe il est marqué les mêmes géodésistes que lans la petite carte des quels ces cantons son tirés. Cette carte et marquée copiée de dessus la carte du Capne Beerings et de Pierre Tchaplin par le Géodésiste Iean Khanikof." 1300 x 540. In the Delisle collection and the title is written in Delisles own hand.

12. "Diese Charte über Sibirien nimt ihren Anfang zu Tobolske ostwerts bis an die euserste Grentze von Sukotskij gemaest unter dem Comando des Capt. Comandeurs Bering Anno 1729". - The map is in British Museum in London. 


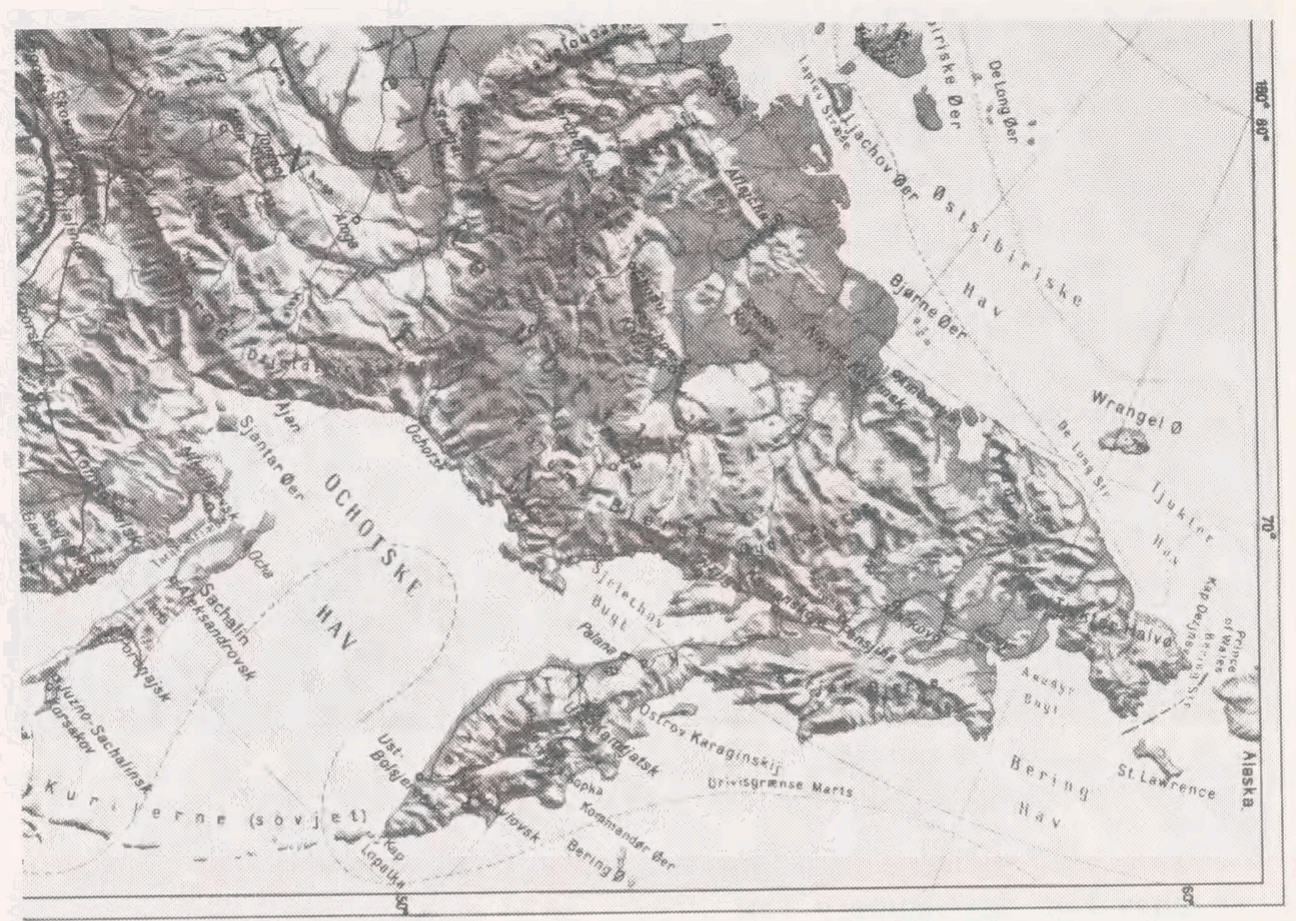

Fig. 8. Udsnit af moderne kort over Nord- og Centralasien (Sovjetunionen). Poul Holmelund og Ib Kejlbo: Gyldendals Relief Atlas, 1968, pl. 41.

\section{Hidtil ukendt Vitus Bering-kort}

For nogen tid siden erhvervede Det kongelige Bibliotek et ikke tidligere publiceret eller registreret, anonymt håndtegnet kort, (fig. 9) der viser Vitus Berings rejserute på den 1. Kamtjatka-ekspedition (1725-30) fra Tobolsk i vest til Kamtjatka i øst.

Midt for kortets $\emptyset$ vre rand er anbragt en kartouche (fig. 10) med forklarende tekst: DENNA CHARTA/är/uprattad öhwer Capitain af Rÿska Flottan Hr/Bergÿngs Ressa ifrån Staden TOBOLSKI/uti/SIBERIEN till TZIKOTZ-KAGO med dess un/derhafwende Commando/A ${ }^{\circ} 1725$.

Kortet måler 560 x $1330 \mathrm{~mm}$ og er en håndkoloreret sepia-tegning forsynet med vandmærke. Det har gradnet med voksende bredder, misvisning er angivet ved Kamtjatkas østkyst og i Anadyr-området.

Uden for selve kortet er ved kortets østside noteret:

Ruth: Gradÿci Tschÿrini. Swe: Graderna uthi Högden:

Ruth: Gradÿci Tschÿrini. Swe: Gradernes Högd: 


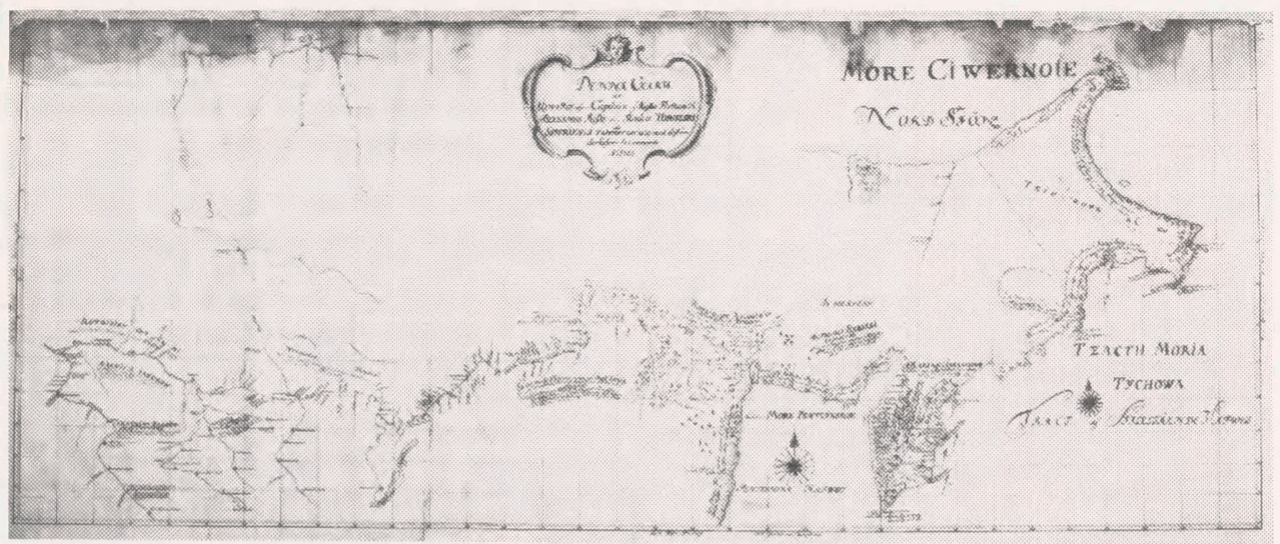

Fig. 9. Anonymt, håndtegnet kort i Det kongelige Biblioteks eje over Berings rejserute på den 1 . Kamtjatka-ekspedition. Udateret. Kortets mål: 56,0 x 133,0 cm.

Forneden på kortet læses midt for rammen:

Ruth: Dlÿni Graducj Swed: Graderne i Længden

Ud over en række topografiske oplysninger så som navne på bjerge, vulkaner, floder, søer og byer m.m. er kortet forsynet med kulturgeografiske legender på russisk og svensk.

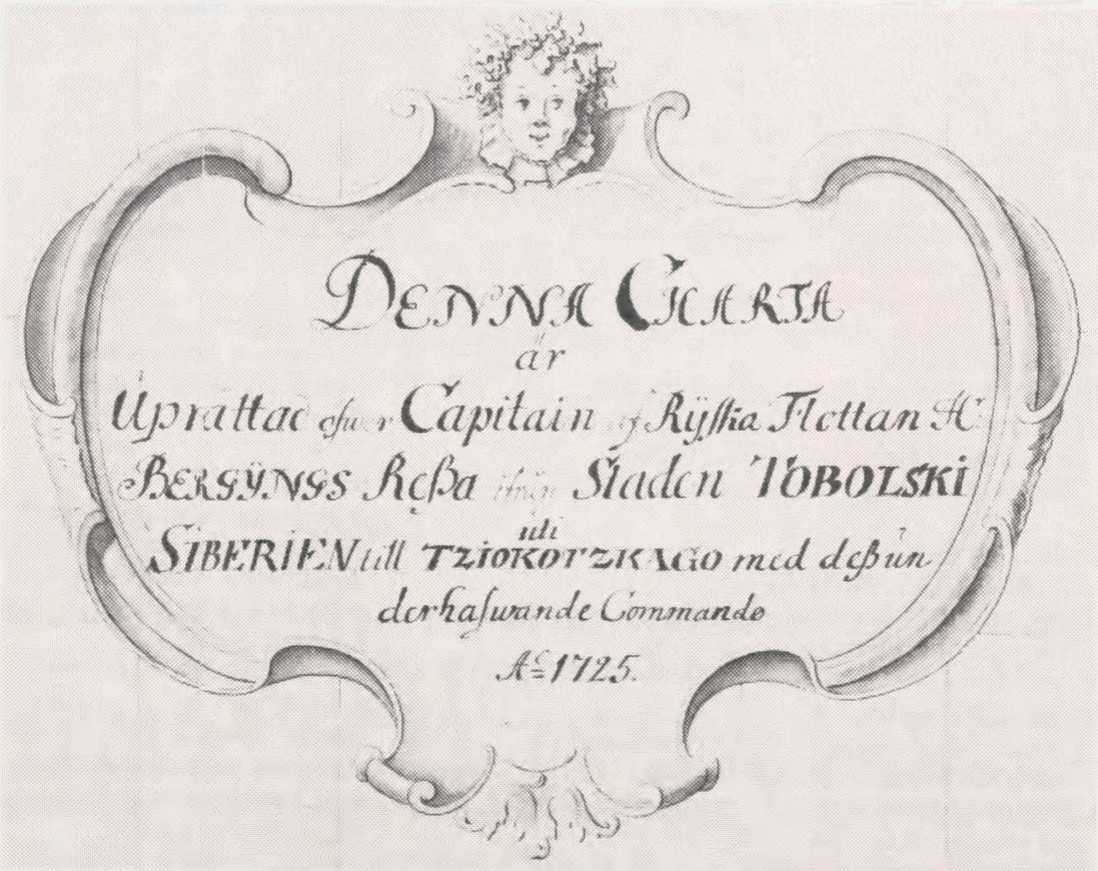

Fig. 10. Kartouche fra Det kongelige Biblioteks anonyme Vitus Bering-kort fra den 1. Kamtjatkaekspedition. 
$72^{\circ}$ n.br., $108^{\circ} \varnothing$ stl.l.

\section{R: MORE CEWERNOJE/ \\ S: Norr Sjön}

$72^{\circ}$ n. br., $112^{\circ} \emptyset$ stl.t.

E: Sche=/egÿn=/skoe Ogul//

S: Schlegÿn=/ska Hörnet/

$70^{\circ}$ n.br., $190^{\circ} \varnothing$ stl.1.

R: Cÿa Tzact Schelagÿnskoi okotom Semlo pålåscheno Spresnich Charti ÿ på wedjamostiam/Denna Tract kallad Schlagÿnskoe är efter=god tÿcke är detta Land oprÿtad och efter förra Chartor sampt erhåldne underrättelser/

$64^{\circ}$ n.br., $116^{\circ}$ østl.1.

R: Krostoio ÿ Ne Malaio/Wisotoia

S: Brahta och utaf ansenlig högd,/ befintelige Berg,./

$62^{\circ}$ n.br., $0^{\circ}$

R: KOTZIOIOT OST IA KI/

$\mathrm{S}$ : Utan någon beständig boning Härwistande OS TIA=ker/

$62^{\circ}$ n.br., $50^{\circ} \varnothing$ stl.l.

R: KOTZOJOI JEKVTY

S: Hÿt och Dÿt flÿttiande Hedningar, kallas JÆKVITER,/

$62^{\circ}$ n.br., $68^{\circ} \varnothing$ stl.l.

R: KOTZIOIOT ALLENIE IA=/CASCHNIE NARODJ TUNGUSI/

S: Här bo Hedningar såkallade Allenje eller Oleni TUN=/=GUSER Men flÿttia snart på det ena, snart det andra stället,/ doch likwähl betala dhe åhrlig Skatt./

R: RuthOng iest ilamutker/

$S$ : Dhe äro ilamutker

$62^{\circ}$ n.br., $84^{\circ} \varnothing$ stl.l.

R: KOTZIOIOT KARIAKI/AASASCHNE/

S: Här är ett slags Hedninger, kallade Karja= /ker, som eÿ Behafwa någon beständig Hem/wist; Men gifwa dochlikwäl/Skatt./

$58^{\circ}$ n.br., $88^{\circ}$ østl.1.

R: KARIAKIIASASCHNE/

S: Skattdragande Karjaker utan någon/ beständig Hemwist eller/Boning/

$60^{\circ}$ n.br., $100^{\circ} \varnothing$ stl.l.

R: $\ddot{y}$ wläte ÿ Pod=snegow ne od Kritwatsche $\ddot{y}$ Mnogüch Miæstak Prÿlegli Kmorÿ/

S: "Sommar och Winter är här continuerlig Snö och många städes Beständig ÿsz, uti Hafwet/sampt Stora Ocean $58^{\circ}$ n.br., $4^{\circ} \emptyset$ stl.l.

R: RASNICH IASYKOW/

S: af åtskillige slags Språck, som dehls änu/äro Hedningar,delhls brachte till den/Rÿska Religion/

$58^{\circ}$ n.br., $72^{\circ} \emptyset$ stl.1.

R: åth seÿ Rekÿ Polosseno på ÿzwästja ÿ Prässnich Chartj Rekj Krutogorowi/

S: jfrån Desse Strömar är alt förrätta efter underättelser och Chartor. Då till Strömen Krutogorowil

58 n.br., $48^{\circ} \emptyset$ stl.1.

R: Od Reckÿ Wÿtÿma wnÿz på Reckj LENIA/ på åbie Stråny KOTZIOT Jacaschne TUNGUSY ÿ/JAKUTJ/

S: Ifrån Strömen Wÿtÿm, och uppa bådde Sÿdor, / LENJA Strömen wistas Tunguser och Jakuter,/ som ey hafwa Boning; Men dock giöra Skatt/till Rÿska Cronan

$54^{\circ}$ n.br., $88^{\circ}$ østl.1.

R: Sÿwut kamzadalj/JASASCHNE

S: Här bor KAMTZADALER, skattgifware,/

R: Rawnig Iaszikow

S: af ett språk/

$56^{\circ}$ n.br., $6^{\circ}$ østl.1.

R: KOTZIOTBARBYN=/SKOYTATTARY/

S: Såkallade Barabÿnskoi Tattarer af obe= /ständig Hemwist, Hvilka och så äro Hedningar/

$56^{\circ}$ n.br., $16^{\circ} \varnothing$ stl.1.

R: KOTZIOIOT/NOWO CHRISTO/NE TATTARI

S: Hÿt och tÿt flÿtiande, och till/den Rÿska Religion brachte/Tattarer/

$50^{\circ}$ n.br., $4^{\circ} \varnothing$ stl.1.

R: Sÿa Brereg Polo=schen prenach Charti/

S: Denna Hafstrand är efter forige upträttade Chartor/

$52^{\circ}$ n.br., $4^{\circ} \emptyset$ stl.l.

S: iamiskewa kräpost. hwarest åhrlig marknad / hålles, emetlan [?] Rÿsarna och Bukarearne, dehras Handel/? [tilføjelse: andet blæk] bestående af Damascher Kartuner etc.:/

$50^{\circ}$ n.br., $8^{\circ} \varnothing$ stl.1.

S: Saltsiö, hwarest åhrlig hämp-/tas Salt till anseende som Spanskt/ Salt, af hwilket hela Siberska Gou=/vernamentet hafwa sitt nödtorfti-/ga Salt./ 


\section{Legenderne}

Hver legende er opdelt i 2 afsnit. Det første afsnit er på russisk - markeret med et $\mathrm{R}$ på kortet, det andet afsnit på svensk - markeret med et $\mathrm{S}$. For at gøre det nemmere at finde en bestemt legende, er hver enkelt af legenderne forsynet med en stedsangivelse (se modstående side).

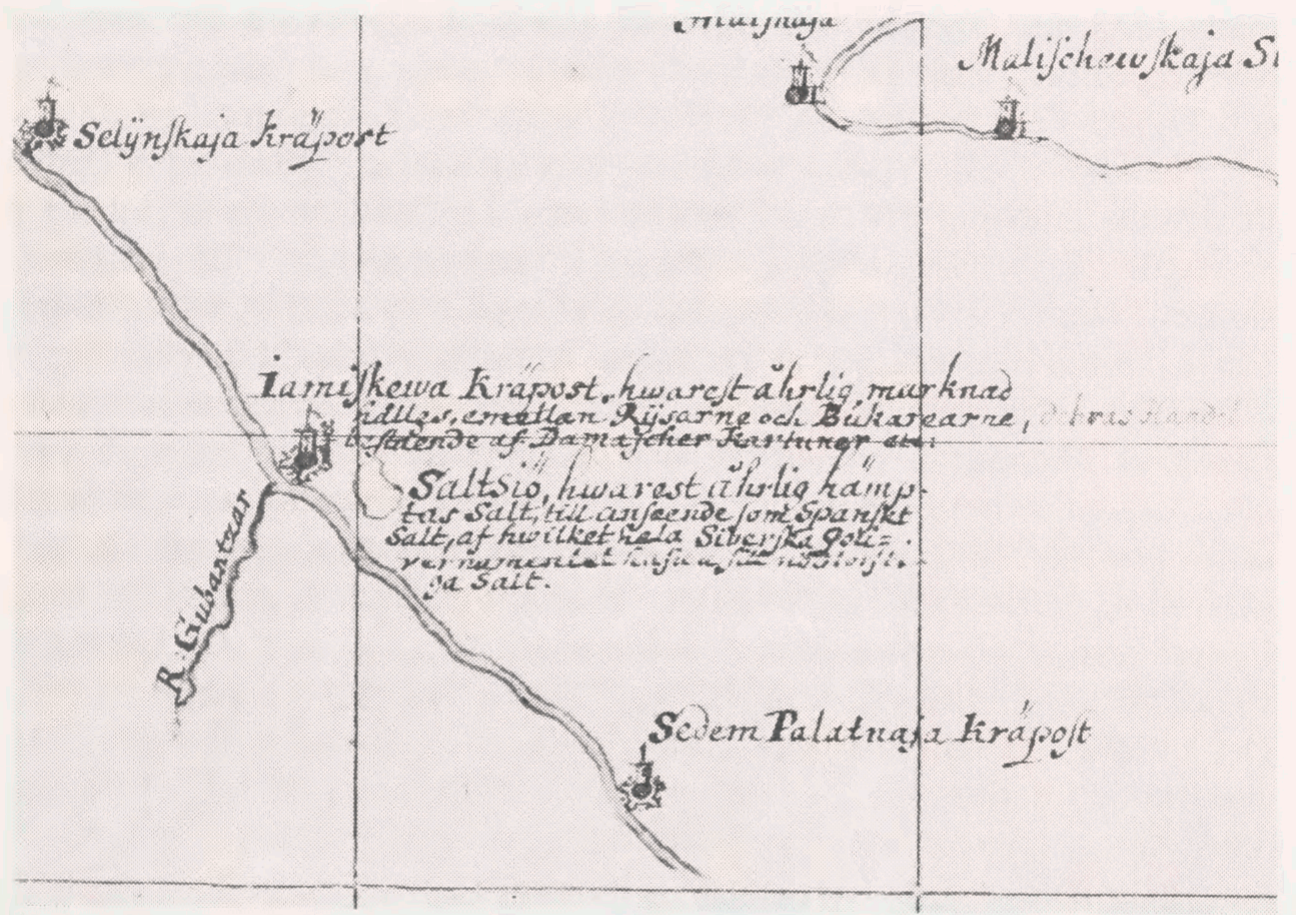

Fig. 11.Legende fra Det kongelige Biblioteks anonyme Vitus Bering-kort fra den 1. Kamtjatkaekspedition. Udsnittet viser Saltsøen, der efter ordlyden forsyner hele Sibirien med salt.

\section{Kamtjatka-ekspedition}

Videnskabenes Akademi troede ikke på Berings rejseresultater fra 1725-1730. For at gøre dets kritik til skamme besluttede han at indgive forslag til, hvordan resultaterne fra den 1 . Kamtjatka-ekspedition kunne bevises, og allerede et par måneder efter hjemkomsten afleverede Bering en plan, der bl.a. indebar, at der ville komme fuldstændig vished om, hvorvidt der var et stræde mellem Asien og Amerika. Planen skulle realiseres ved, at et skib skulle bygges på Kamtjatka, og dette skulle så sejle langs Amerikas vestkyst. 
Han skulle endvidere opsøge søvejen fra Kamtjatka til floden Amur og Japan, og han skulle kortlægge nordkysten af Sibirien fra Ob og Jenisej og derfra til Lena.

Den 2. Kamtjatka-ekspedition tog sit udgangspunkt i St. Petersborg den 1. februar 1733. Danskeren Martin Spangberg satte kurs mod Okotsk, hvor han skulle intensivere bygning af de skibe, som skulle anvendes ved kortlægningen af Stillehavskysten. Bering brød op noget senere, nemlig den 18. marts 1733 med Tobolsk som rejsemål. Herfra skulle nemlig den første ishavsekspedition udgå. Til dette formål lod Bering bygge to skibe, og de afgik den 30. juni 1735 fra Jakutsk.

Ishavsekspeditionernes arbejdsopgaver var opdelt regionalt. Fra floden Petschoras munding til $\mathrm{Ob}, \mathrm{og}$ fra $\mathrm{Ob}$ vestpå til Golovin. Fra Ob og $\varnothing$ stpå kortlagde Ofzyn kyststrækningen fra Ob til Jenisej. Det ene skib - dobbeltsluppen "Jakutsk" - var under kommando af løjtnant Prontschischtsschef, derudover bestod bemandingen af Tjeljuskin, landmåler Tschekin og omkring 50 mand. Det andet skib - dæksbåden Irkutsk - var under den danskfødte Peter Lassenius' kommando, en dansker man desværre ikke kender meget til. Foruden Lassenius bestod bemandingen af styrmand, landmåler og omtrent 50 andre personer. "Jakutsk" skulle sejle fra Lenas munding og runde Tajmirhalvøen og derefter sejle ind i Jenisej. "Irkutsk"s chef havde ordrer til at følge ishavskysten mod $\emptyset$ st og blandt andet unders $\emptyset$ ge, hvorvidt der fandtes et stræde mellem Asien og Amerika. Malygin og Skuratof kortlagde kysten i Det kariske Hav og Ob-bugten, Ofzyn kortlagde kyststrækningen fra Ob til Jensisej og Chariton Laptjef knyttede forbindelsen mod vest. Hans styrmand Tjeljuskin betrådte 1742 den gamle verdens nordligste spids, som blev opkaldt efter ham.

Inden den 2. Kamtjatka-ekspedition forlod St. Petersborg i foråret 1741, fik Bering og Tschirikof udleveret et kort af kommissionen for ekspeditionen. Det var udarbejdet af den franske geograf Joseph Nicolas Delisle. Denne var i russisk tjeneste og havde desværre tegnet kortet på grundlag af forældet kartografisk materiale. Kortet skulle Bering anvende under sejladsen, lød ordren fra kommissionen. Denne var enten ikke informeret eller tog med vilje ikke hensyn til det nyeste kartografiske materiale, der fandtes. Det skulle få katastrofale konsekvenser. Kortet var nemlig fyldt med forkerte og vildledende oplysninger, således betegnelserne: Gama-Kompagni- og Staatenland samt Jeco, skønt de hvilede på gale efterretninger og kartografiske fejltagel-

Joseph Nicolas Delisle udtalte på grundlag af kortet, at den letteste vej til Amerika ville være at stå ud mod sydøst fra Avatscha-bugten til Gamalandets nordspids, sikker på disse landes beliggenhed samt deres afstand fra Kamtjatka. Denne udlægning er imidlertid gal - et forhold, som man burde 
have været klar over, idet den tidligere omtalte Spangberg 2 år før havde oversejlet både "Kompagni Staaten" og "Jecoland". Kommissionen besluttede imidlertid, at ekspeditionen først skulle søge Gamalandets nordkyst (som ikke eksisterede), sejle østpå til Amerika og derefter vende om. De sejlede mod sydøst således, som Kommissionen havde befalet, og det gjorde de 600 mil, ad $46^{\circ} 9^{\prime}$ n.br. til $14^{\circ} 30^{\prime} \emptyset$ st. for Avatscha. Efter Delisles kort skulle de da forlængst have været nået frem til Gamaland, og Bering gav ordre til at vende om.

Bering var på det tidspunkt allerede angrebet af skørbug. Han sejlede nordpå, og endelig efter halvanden måned observerede de land. Højden var $58^{\circ} 14^{\prime}$ n.br. og $49^{\circ} 30^{\prime} \varnothing$. fra Avatscha. Kysten så ikke indbydende ud. På det sønderrevne land hævede sig en kæmpemæssig vulkan. Det var Sct. Elias. Bering havde opdaget Amerika fra $\varnothing$ st. Den 20. juli ankrede de op ved en $\emptyset$, som de kaldte Sct. Jlii (Sct. Elias) efter dagens helgen. Nogle få timer undersøgte nogle af deltagerne øen, bl.a. for at hente vand. Der blev fundet rester af menneskelig foretagsomhed: aske fra et ildsted, en barkkurv og en del røget fisk. Bering efterlod som gave til de ikke sete beboere noget tobak, en kinesisk pibe og et stykke silketøj.

Bering sejlede nu mod sydvest og passerede flere gange den Aleutiske Ørække. Vejret var næsten hele tiden stormfuldt. Mandskabets fysiske og

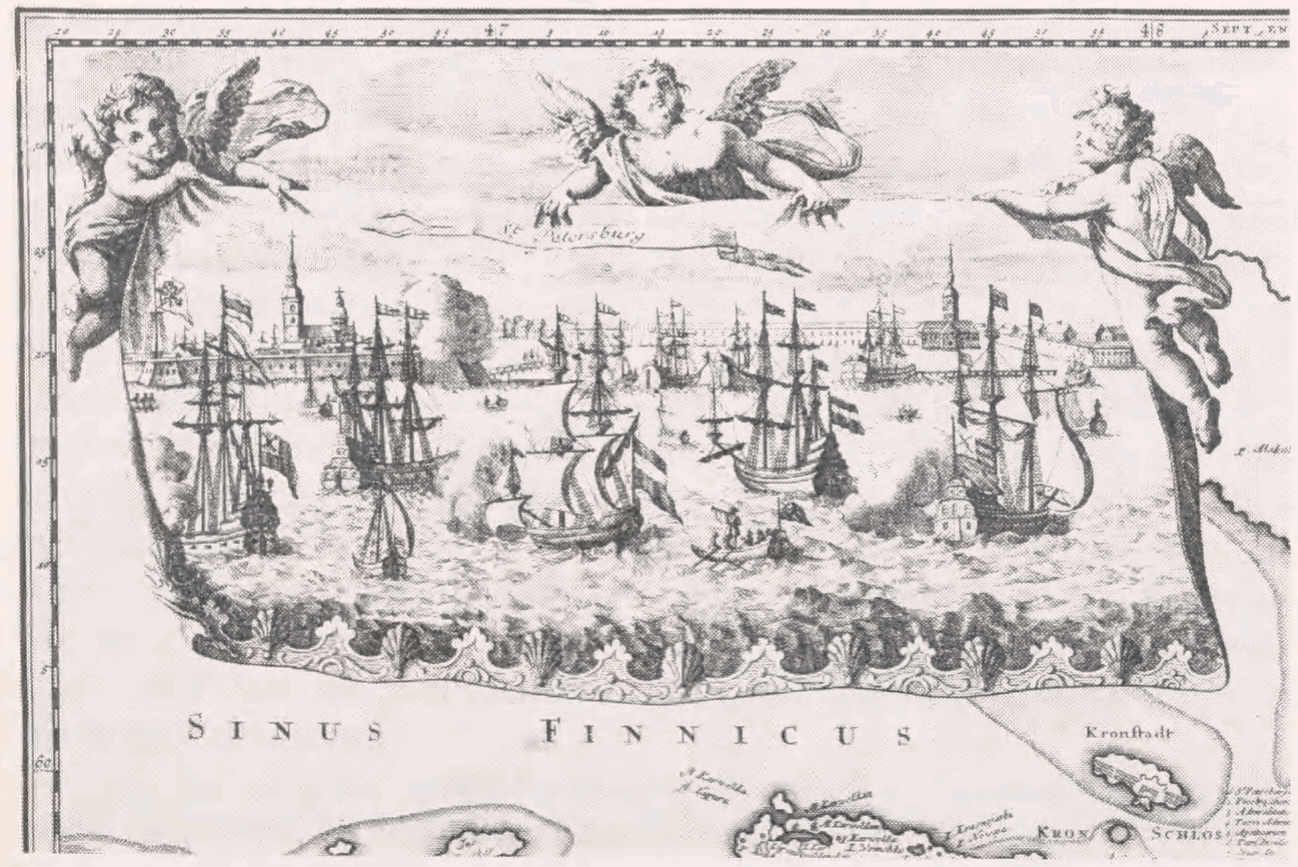

Fig. 12. Vignet med St. Petersborg fra Homanns Arvingers kobberstukne kort over Ingermanlandiæ seu Ingriæ... 1734. Frederik den Femtes Atlas bd. 44, pl. 61. 
psykiske tilstand var elendig. Skørbugen var begyndt at kræve sine ofre. Da man den 4. november endelig så land, troede de fleste, at man endelig var nået frem til Kamtjatka. Men istedet var de havnet på det, der senere er blevet kaldt Bering $\varnothing$, og hvor ekspeditionen led skibbrud.

Både blandt søfolkene på skibet og senere blandt dem, der var kommet i land, bukkede mange under, Bering selv døde den 8. december 1741, liggende $\mathrm{i}$ en lille sandhulning. Svend Waxel, som havde fåt kommandoen over ekspeditionen efter Berings død, opmuntrede mandskabet og foreslog dem at bygge et nyt skib, baseret på materiale fra det gamle. Ingen af de overlevende var tømrere eller skibsbyggere, men alligevel fik de ved en imponerende indsats bygget et særdeles sødygtigt skib, som blev søsat den 10 . august 1742. Den 26. august anløb de Avatscha, og dagen efter ved Petropolovsk på Kamtjatka. Ekspeditionen var vendt tilbage til sit udgangspunkt. 